\title{
赤血球の保存に及ぼす擋汼の効果
}

\author{
大熊 重則 宇多 正行 石居 昭夫 西崎太計志 \\ 岡山県赤十字血液センター
}

（昭和61年11月18日受付）

\section{THE EFFECTS OF CONTINUOUS AGITATION ON PRESERVATION OF RED BLOOD CELLS}

\author{
Shigenori Ohkuma, Masayuki Uda, Akio Ishii and Takeshi Nishizaki \\ Japanese Red Cross Okayama Blood Center
}

To evaluate the effects of agitation on preservation of red blood cells, the cells were stored in citrate-phosphate-dextrose solution at 4 to $6^{\circ} \mathrm{C}$ for 35 days under two types of continuous agitation, reciprocal flat-bed and circular agitation. The $\mathrm{pH}, 2,3$-diphosphoglycerate (2,3-DPG) level, adenosine triphosphate (ATP) level, morphology score and hemolysis were measured at weekly intervals. When $200 \mathrm{ml}$ polyvinylchloride (PVC) bags were used, both types of agitation showed better preservation of red cells as evaluated by morphology score than non-agitation, but there was no significant improvement in the $\mathrm{pH}$ and levels of 2,3-DPG and ATP with either type of agitation. On the other hand, when stored in $600 \mathrm{ml}$ PVC bags, agitation maintained much higher 2,3-DPG levels and morphology scores throughout storage. Flat-bed agitation did not increase hemolysis during 28 days of storage compared with non-agitation, but circular agitation caused marked hemolysis from 7 days on. These data indicate that a gentle mode of agitation and large bag size are important to preservation of red cells. Continuous flat-bed agitation seems to be effective in better maintenance of both oxygencarrying capacity and viability of red cells during storage without causing mechanical injury to the cells.

\section{緒 言}

輸血用赤血球の保存に拈ける重要な課題は赤血 球の viability と酸素運搬能をできるだけ長く維 持することである. Viability はATP レベルや赤 血球形態と密接な関係を有すると言われており， これらは最近新しい保存液の開発などによってか なり改善されてきた。しかし，酸素運搬能に関係 する2,3-DPG レベルは保存中の低下が特に速く, これを維持する有用な方法はいまだ確立されてい ない.

これまで，2,3-DPG レベルを改善するためのア プローチの 1 つとして，保存中擋挥することに よって $\mathrm{pH} レ$ レ゙ル維持しょらとする試みがあ る122).これは, 2,3-DPG が $\mathrm{pH}$ に敏感であること を利用している3 ${ }^{3)}$ しかし, CPD 液では擋挥の効果 は小さく, bicarbonate bufferのような物質を添
加する必要があること年2)，また赤血球が擋汼に よって損傷を受け易く，溶血が増加することなど が問題とされて扣り ${ }^{4)}$, 擋挥の有効性は必ずしも 明らかではない。

そこで我々は, 赤血球保存に括ける擋拌の効果 をより明確にするため, 擋挥モードや血液バッグ の大きさなどを変え, 赤血球保存に及ぼす擋汼の 影響について多面的に検討した。すなわち，穏や かな擋汼 (flat-bed 振盪) 及び強い擋汼 (circular 振盪)の 2 種の振盪モードを用い, それらの効果 について静置保存と比較した。 また，バッグのガ ス透過効率を高くする観点から, 従来の $200 \mathrm{~m} l$ bag より表面積が約 2 倍の $600 \mathrm{~m} l$ bag を用いて赤 血球を振盪保存し，その効果について検討した。 振盪の効果の得失を評価する指標として, 赤血球 の保存中の $\mathrm{pH}, 2,3-\mathrm{DPG}$ レベル, ATP レベル, 
morphology score, 及び溶血率を用いた。

\section{方法}

本研究で用いた濃厚赤血球は日本赤十字社業務 標準5り基づいて製造した。 血液バッグは, 通常の 大ささの $200 \mathrm{~m} l \mathrm{PVC}$ bag（カワスミ, KBP-200, 表面積：約 $250 \mathrm{~cm}^{2}$ ) と, 表面積が約 2 倍の $600 \mathrm{~m} l$ PVC bag（カワスミ, KBP-600, 表面積 : 約508 $\mathrm{cm}^{2}$ )を用いた。

濃厚赤血球の振盪には, circular 型 (face to face モード) 振盪機 (Helmer platelet agitator model PA-4, 6rpm) 及び reciprocal 型 flat-bed 振 盪機（Taiyo R-1改良型6)，50cpm）を用いた。

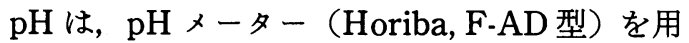
いて測定し, ATP 值は ATP kit (BMY 社, No. 123897)を，2,3-DPG 值は2,3-DPG Kit (BMY 社, No. 148334）をそれぞれ用いて測定した。溶血率 は tetramethylbenzidine 法7を用いて測定した。 Morphology score は, 赤血球の形態を Bessis の 報告8) に基づいて分類し，これに我々が既に報告

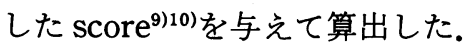

測定值はすべて mean $\pm S D$ で示し, 統計学的有 . 意差検定はStudent の $\mathrm{t}$ 検定を用い, $\mathrm{p}<0.05$ の 場合を有意とした。

\section{結果}

Reciprocal 型水平振盪及び circular 型転倒振 盪の 2 種類の振燙モードを用いて赤血球を振盪保 存し, 保存中の $\mathrm{pH}, 2,3-\mathrm{DPG}, \mathrm{ATP}$, morphology score 及び溶血率について静置保存と比較した。

$200 \mathrm{~m} l$ bag を用いた場合の $\mathrm{pH}$ は, flat-bed 及 び circular モードによる振盪保存が静置保存よ りも若干高い傾向を示したが，統計学的有意差は なかった（Fig. 1-a). $600 \mathrm{~m} l$ bag を用いた場合， いずれの振燙方法によっても $200 \mathrm{~m} l$ bag の静置 保存 (以下 control と称す) より若干高値を示した が, 静置, flat-bed 振盪及び circular 振盪の三者の 間には大きな差はなかった（Fig. 1-b).

2,3-DPGにおいては, $200 \mathrm{~m} l$ bag を用いた場 合, circular 振盪が静置保存に比べ若干高値を示 したが，個体差によるバラッキが大きく，三群の 間に統計学的有意差はなかった (Fig. 2-a). 600 $\mathrm{m} l$ bag を用いた場合，静置保存においても2,3-
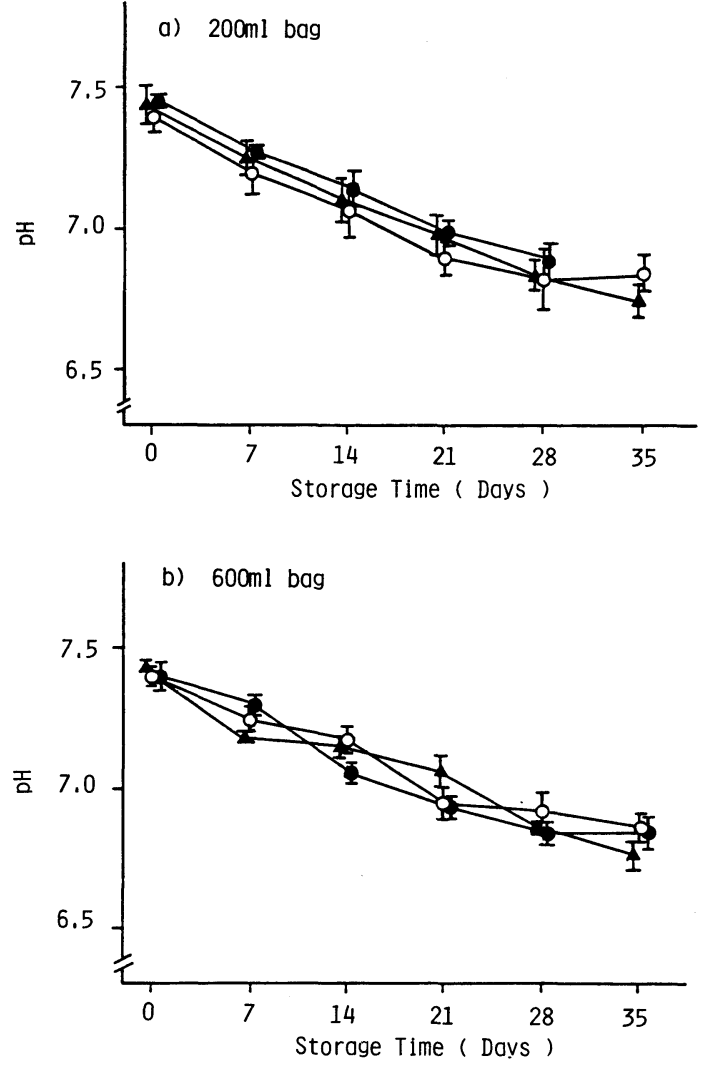

Fig. 1 Plasma pH of red blood cells stored at 4 $\sim 6{ }^{\circ} \mathrm{C}$ under non-agitation ( $\mathrm{O}-$ ), flat-bed agitation (- - ) and circular agitation ($-)$. Data are mean $\pm \operatorname{SD}(n=5)$.

DPG レベルがかなり良好に維持される傾向を示 し，さらに振盪を行うと保存 7 ～21日に拈いて control より有意に高値を示した $(\mathrm{p}<0.05)$. しか し, circular 振盪では, 予想に反して余り大きな効 果は得られなかった（Fig. 2-b). 保存14日後の2, 3-DPG 值を比較すると, control が初期值の約 $36 \%$ あるるのに対し, $600 \mathrm{~m} l$ bag 静置保存が約 $57 \%$, flat-bed 振盪が約 $70 \%$ と良好に維持された。

ATP 值はいずれの bag, いずれの振盪モードに おいても大きな差はなかった（Fig. 3).

Morphology score に拈いては, control が保存 28 日以降急激に低下するのに対し， $200 \mathrm{~m} l$ bag を 用いた振盪保存ではいずれも28日以降有意に高レ ベルに維持された（Table $1, \mathrm{p}<0.05 ） 。$ また600 $\mathrm{m} l$ bag を用いた場合は, 静置保存においても 
Table 1 Morphology scores of red blood cells stored at $4 \sim 6^{\circ} \mathrm{C}$ under non-agitation, flatbed agitation and circular agitation

\begin{tabular}{|c|c|c|c|c|c|c|c|c|}
\hline \multirow{2}{*}{ Bag } & \multirow{2}{*}{ Agitation } & \multicolumn{7}{|c|}{ Storage Time (days) } \\
\hline & & 0 & 7 & 14 & 21 & 28 & 35 & 42 \\
\hline \multirow[t]{3}{*}{$200 \mathrm{~m} l$ bag } & non-agitation & 300 & $294 \pm 4$ & $278 \pm 5$ & $249 \pm 18$ & $206 \pm 37$ & $112 \pm 32$ & $68 \pm 15$ \\
\hline & flat-bed agitation & 300 & $283 \pm 2$ & $282 \pm 3$ & $273 \pm 8$ & $262 \pm 13$ & $229 \pm 25$ & $159 \pm 43$ \\
\hline & circular agitation & 300 & $292 \pm 4$ & $285 \pm 5$ & $285 \pm 10$ & $280 \pm 6$ & $257 \pm 18$ & $214 \pm 29$ \\
\hline \multirow[t]{3}{*}{$600 \mathrm{~m} l$ bag } & non-agitation & 300 & $271 \pm 6$ & $273 \pm 8$ & $271 \pm 9$ & $261 \pm 19$ & $220 \pm 5$ & $142 \pm 20$ \\
\hline & flat-bed agitation & 300 & $285 \pm 8$ & $285 \pm 10$ & $277 \pm 13$ & $273 \pm 7$ & $234 \pm 30$ & $189 \pm 36$ \\
\hline & circular agitation & 300 & $290 \pm 4$ & $287 \pm 5$ & $278 \pm 9$ & $271 \pm 19$ & $243 \pm 33$ & $145 \pm 41$ \\
\hline
\end{tabular}

Values are based on a maximum of 300 and expressed as mean $\pm \operatorname{SD}(n=5)$
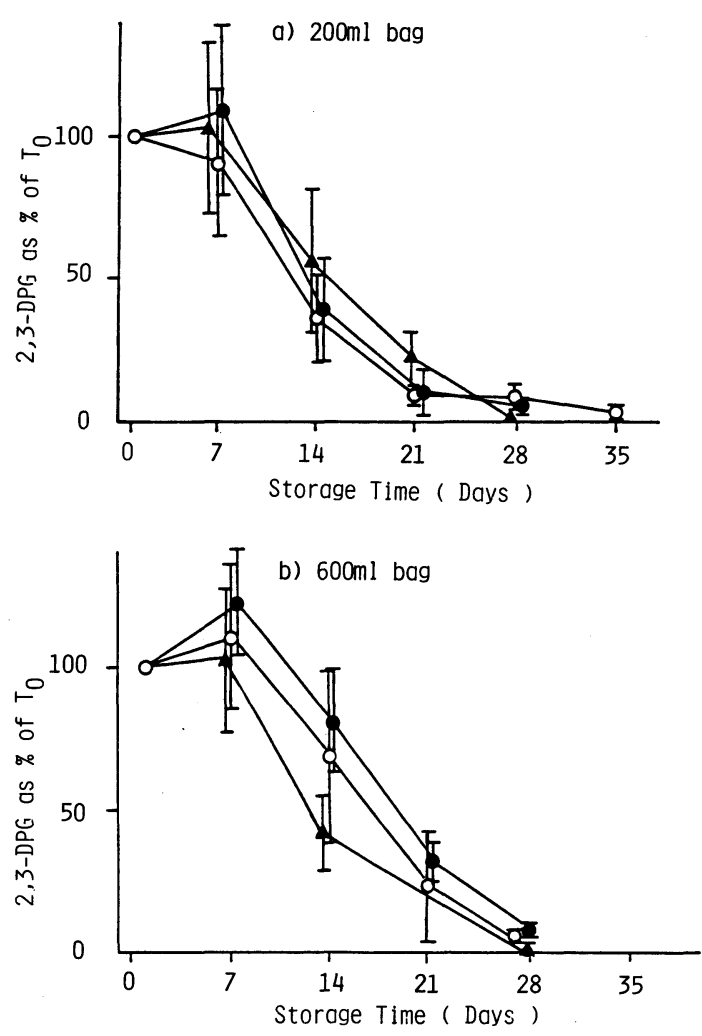

Fig. 2 2,3-DPG levels of red blood cells stored at $4 \sim 6{ }^{\circ} \mathrm{C}$ under non-agitation $(-\mathrm{O}-)$, flat-bed agitation (- $\rightarrow$ ) and circular agitation $(-\boldsymbol{\Delta}$ $-)$. Data are mean $\pm \mathrm{SD}(\mathrm{n}=5)$.

controlよりも高いscore を示し（28日以降：p< 0.05), flat-bed 振盪ではさらに良好に維持される 傾向を示した。

溶血率は, $200 \mathrm{~m} l$ 及び $600 \mathrm{~m} l$ のいずれのバッグ を用いても circular 振盪に拈いて著しい増加が
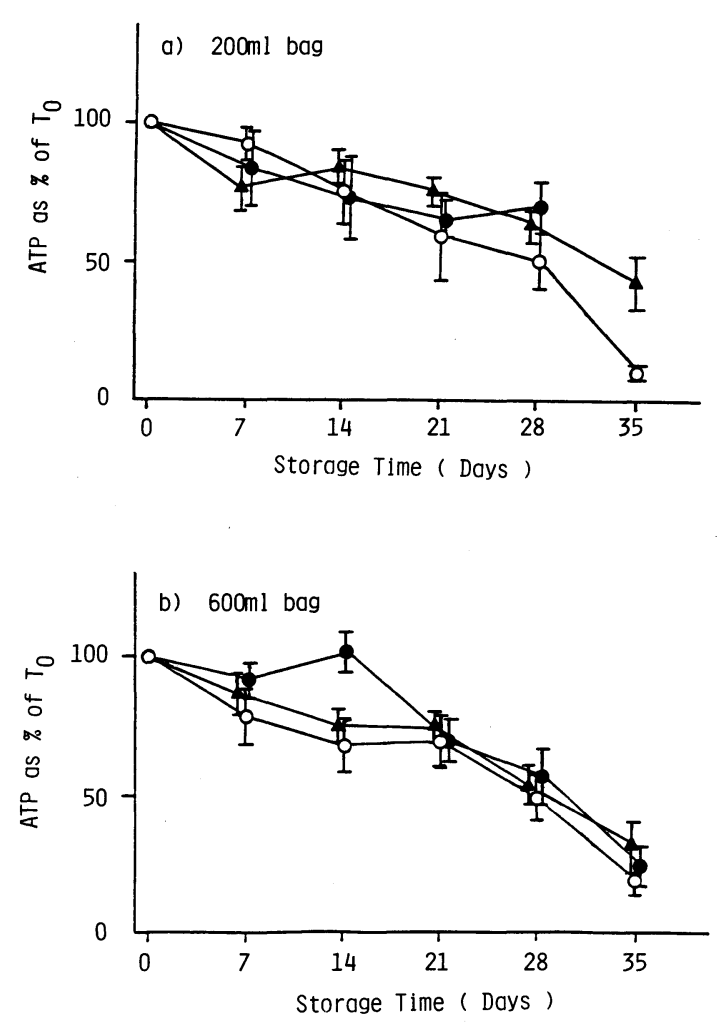

Fig. 3 ATP levels of red blood cells stored at 4 $\sim 6{ }^{\circ} \mathrm{C}$ under non-agitation (-O-), flat-bed

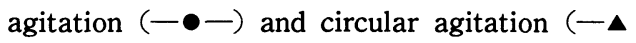
$-)$. Data are mean $\pm S D(n=5)$.

認められ (Fig. 4-a, b)，いずれも 7 日以後は他の 二群より有意に高値を示した $(\mathrm{p}<0.05)$.また, $200 \mathrm{~m} l$ bag を用いた flat-bed 振璗では control と ほぼ同等であったが, $600 \mathrm{~m} l$ bag を用いた flatbed 振盪では，保存28日以降に拈いて溶血が抑制 

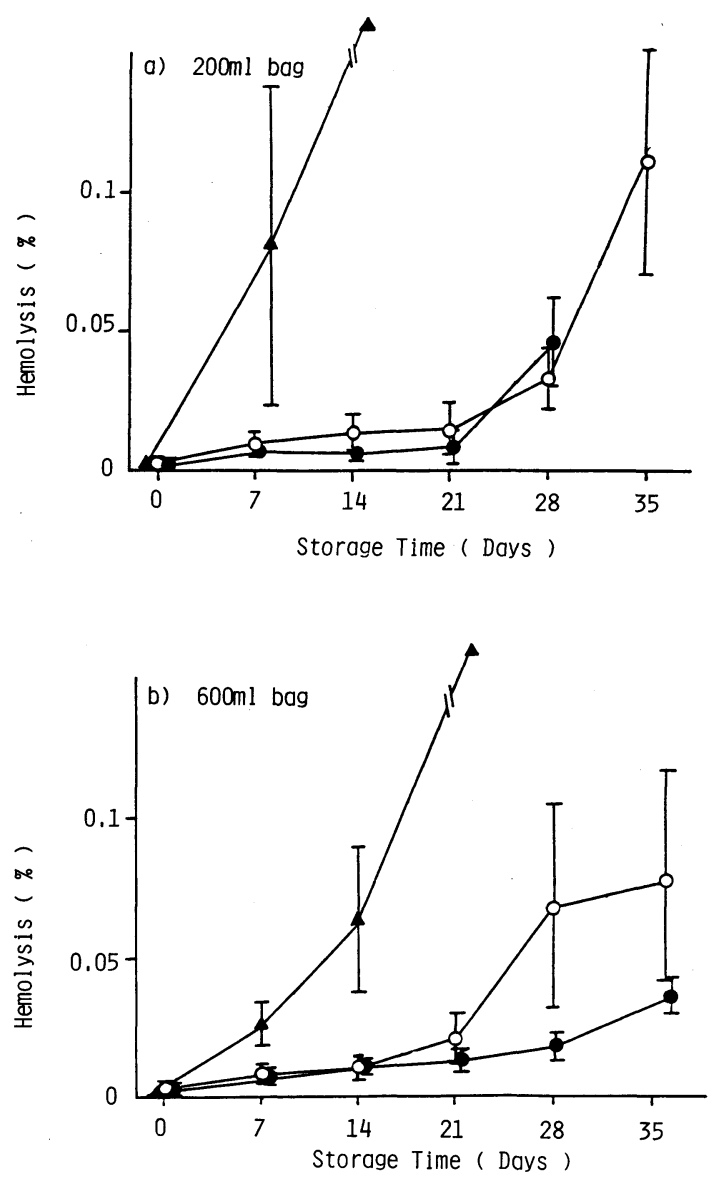

Fig. 4 Hemolysis of red blood cells stored at 4 $\sim 6{ }^{\circ} \mathrm{C}$ under non-agitation (-O-), flat-bed agitation (- - ) and circular agitation (-). Data are mean $\pm \mathrm{SD}(\mathrm{n}=5)$.

される傾向が認められた。

\section{考察}

赤血球の保存中，擋拌することによってその保 存状態を改善しょうとする試みはこれまでいくつ か報告されているが(12)4)，その擋拌の方法と得ら れる効果の得失の関係は明らかでなかった。我々 は本研究に招いて，擋挥の利点を有効に得るには 表面積の大きな血液バッグの使用と穏やかな振燙 モードの選択が重要であることを示した。

今回の実験では，穏やかな擋找モードとして reciprocal flat-bed 振盪を，また激しい擋汼モー ドとして circular（face to face）振盪を選び，静 置保存と比較した。その結果，通常の $200 \mathrm{~m} l$ bag
を用いた場合は，いずれの振盪を加えても $\mathrm{pH}$ 2,3-DPG レベルに顕著な改善はみられず，逆に著 明な溶血が circular 振盪に拈いて認められた。一 方， $600 \mathrm{~m} l$ bag を用いた場合は，2,3-DPG レベル が振盪によって大きく改善されることが示され た。この場合も flat-bed 振盪では溶血の増加はみ られなかったが，circular 振盪では溶血が顕著に 増加した。

以上の事実から，擋拌によって2,3-DPG レベル を改善するには通常の大きさのバッグ $(200 \mathrm{~m} l)$ で は不十分であり，擋汼効率を高めるための何らか の工夫がバッグ側にも必要であることがわかっ た. Beutler 等 ${ }^{1}$ は，バッグの表面積 $(\mathrm{S})$ と血液量 (V) の比率 ( $\mathrm{S} / \mathrm{V}$ 比) $か ゙ 0.9 \mathrm{~cm}^{2} / \mathrm{m} l$ の ものと2 $\mathrm{cm}^{2} / \mathrm{m} l$ のものを比較し, 後者が2,3-DPG レベル に対して良好であったことを報告している，今回 我々が用いた $600 \mathrm{~m} l$ バッグの $\mathrm{S} / \mathrm{V}$ 比は $4.2 \mathrm{~cm}^{2} /$ $\mathrm{m} l$ とさらに大きく，その結果擋汼効率や $\mathrm{CO}_{2}$ ガ スの放出効率が向上し，2,3-DPG レベルが高值に 維持されたものと考えられる，たとえば，14日目 の2,3-DPG 值を比較すると, $600 \mathrm{~m} l$ bag の flatbed 振盪保存が $200 \mathrm{~m} l$ bag の静置保存の約 2 倍の 值を示した. 血小板保存ではすでにこの $\mathrm{S} / \mathrm{V}$ 比が

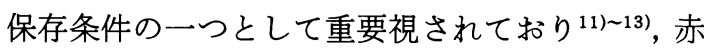
血球保存に扮いても今後この観点からの詳細な検 討が必要となろう。また最近，ガス交換率を高め る工夫の一つとして薄膜のバッグを用いた赤血球 保存なども試みられて扣り ${ }^{14)}$ ，同様の意味に打い て興味深い。

もら一つの重要な知見は，擋挥力は穏やかな flat-bed 振盪で十分であり, circular モードのよ らな転倒型振盪は赤血球に対してストレスが強過 ぎ，溶血の上昇をもたらすということである。 Shields ${ }^{4}$ は laboratoy mixing standによる agitationを 1 日 1 時間行った場合, 保存日数が長 くなるにしたがって溶血が増加することを報告し ている，確かに保存日数が長くなると，赤血球膜 の脆弱化が進み溶血し易くなると考えられるが， より重要なのは振盪モードの選択であろう。実際 に, 今回用いた flat-bed 振盪では, 保存日数が長く なっても，また保存中連続的に振盪しても，静置 
保存と同等もしくはそれ以下の溶血率に留った。

今回の研究では, 主として2,3-DPGレベルの改 善を目的として擋拌を行ったが，その効果は2,3DPGレベルだけでなく, 赤血球の viability の向 上にも寄与していることが認められた。すなわち， in vivoの viabilityによく相関すると言われてい る morphology score ${ }^{9)}$ はいずれの振盪方法に よっても顕著に高値を維持することがわかった。

これらのデーターは, Dern 等 ${ }^{15)}$ が血液を擋挥する ことによって赤血球の in vivo の生存率が上昇し たといら報告ともよく一致する。 また, circular 振 盪においても溶血率は高くなるが, morphology score が良好に維持されていることを考慮する と, 振盪によって溶血するのは生体内ですでに老 化していた一部の赤血球だけであり，それ以外の 赤血球はかなり激しい振盪に対しても耐性を有す る可能性が推定される。すなわち，擋汼は本質的 には赤血球の viability 改善する効果を示すと 考えられる。いずれにしても, 実用的には flat-bed 振盪のような穏やかな振盪モードが, 溶血を増加 させることなく血球の寿命に好影響を及ぼすの で，より安全な擋挥方法と言えよう。

以上のように，擋找によって2,3-DPGレベル及 び morphology scoreを良好に維持することがで きるので, これは赤血球の酸素運搬能と viability の両者の改善につながると考えられる。しかし， 擋䢁効果の作用機構については必ずしも明確では ない. 我々の予測では擋汼はバッグの $\mathrm{CO}_{2}$ 放出効 率を高め, その結果 $\mathrm{pH}$ の低下を抑制し,引いては 2,3-DPG やATP レベルが良好に維持されると考 えられた。確かにこの効果も認められるが，擋拌 による実際の $\mathrm{pH}$ の上昇はそれほど大きなもので はなかった。このことから，擋拌の効果は単にみ かけの $\mathrm{pH}$ の維持だけに因るのではなくむしろ赤 血球が一定の場所に滞留したり集積することが防 げられ，常に一様に混合された血浆中に浮遊され ることが重要な因子であると推定される.例えば, 赤血球が一定の場所に滞留すると, その回りの $\mathrm{pH}$ の低下などによる局所的環境の劣化が起こ り，赤血球の代謝が大きな影響を受けることは十 分あり得ると考兄られる.Beutler ${ }^{2}$ は，バッグを 糈置きで静置保存した時，“top”より“bottom”の 方が ATP 2,3-DPG レベルの低下が大きいこと を報告しているが，これも局所的環境に基づく差 を示す一例であると思われる。 また, 静置保存で は“bottom”の部分に赤血球が集積するので，その 部分の $\mathrm{Ht}$ 值は極端に高くなる. そのため, 赤血球 間の直接的な接触が強くなり, 結果的に赤血球形 態の劣化や溶血が起こり易くなることが推測され る. 実際に, Ht 值が高くなると溶血が増加するこ と ${ }^{16)}$ ，また血奨の存在が溶血の抑制に有効である ことが報告されてお括り ${ }^{16)}$ ，上記の推定が支持され る.

従来，2,3-DPG レベルを上昇させる方法として は, inosine 17)18), ascorbat $\mathrm{e}^{19)}$, dihydroxyacetone ${ }^{19) 20}$, phosphoenolpyrvate $(\mathrm{PEP})^{21)}$ な゙の化学物質を添加し, 赤血球の代謝 を活発化させる方法が数多く試みられてきた。こ れらの方法は確かに2,3-DPG レベルの維持には有 効であるが, PEP 以外はむしろ ATP レベルを低 下させる傾向がみられる。をた, inosine は生体に 対する毒性が危惧され，またその他の化合物はい ずれも熱に不安定である（バッグのオートクレー ブ滅菌が困難）などの問題があり，いまだ実用化 されるに至っていない。このような状況を考える と，バッグの改良と擋挥効果を利用する方法は, 2,3-DPG レベルを維持するための一つのアプロー チとして有効であろう。

しかし，本法を実用化するためにはなおいくつ か解決すべき課題がある。たとえば， $600 \mathrm{ml}$ バッ グは現行のバッグに比べてかなり大型であるの で，遠心時などに执いてその取扱いが不便である。 一つの解決策として, 現行の $200 \mathrm{~m} l$ バッグをダブ ルタイプとして全表面積を $600 \mathrm{~m} l$ バッグと同等 にする方法が考えられる。また，擋汼を如何にし て簡便に実施するかについても検討する必要があ る. 血小板保存に一般に利用されているラック付 水平振盪機の大型化が有用かも知れない.

最後に, 本法によっても保存21日以後の2,3DPG レベルの改善はなお不十分である.このため には，バッグを大きくするだけでなく，材質的に ガス透過性の優れた新しいバッグを開発すること 
も必要と思われる，いずれにしても，赤血球を保 存中穏やかに擋拌することによって大きな効果が 得られることが示唆されたので, 今後この原理を 応用した赤血球の保存法の改良についてさらに検 討する価値があると思われる。

\section{まとめ}

赤血球の保存に及ぼす擋拌の効果を検討し，以 下の知見を得た。

（1）通常の $200 \mathrm{~m} l$ バッグを用いた場合は，2,3DPG や ATP レベルの改善は小さかったが, 表面 積が約 2 倍の $600 \mathrm{~m} l$ バッグを用いると擋拌の効 果が顕著となり, 特に2,3-DPG 及び morphology score が良好に維持された。

（2）転倒回転モードの circular 振盪では，溶血 が著しく増加したが, reciprocal 型 flat-bed 振燙 では, 静置保存と同等, またはそれ以下の溶血率 に留った。

以上のように, $600 \mathrm{~m} l$ バッグを用いて水平振盪 を行えば, 溶血が増加することなく赤血球の酸素 運搬能（2,3-DPG）と viability の両者にかなりの 改善が認められた. 赤血球保存に掞いて擋汼を有 効に働かせるには, バッグを大きくすること, 及 び穏やかな振盪モードを選択することが重要であ ると考えられる。

\section{文献}

1) Beutler, E. and Wood, L.A.: Preservation of red cell 2,3-DPG and viability in bicarbonate containing medium: The effect of blood-bag permeability. J. Lab. Clin. Med., 80 : 723-728, 1972.

2) Wood, L.A. and Beutler, E.: The effect of periodic mixing on the preservation of 2,3-diphosphoglycerate (2,3-DPG) levels in stored blood. Blood, 42 : 17-25, 1973.

3) Beutler, E., Meul, A. and Wood, L.A.: Depletion and regeneration of 2,3-diphosphoglyceric acid in stored red blood cells. Transfusion, 9 : 109-114, 1969.

4) Shields, C.E. : Studies on stored whole blood. IV. Effects of temperature and mechanical agitation on blood with and without plasma. Transfusion, 10:155-162, 1970.

5）日本赤十字血液センター業務標準：技術部門。日 本赤十字社血液事業部，1985年度版。

6）宇多正行, 岡田英俊, 内藤俊二, 石居昭夫, 西崎
太計志：CPD 液を用いた濃縮血小板の調製法と 保存法についての検討. 血液事業, $6: 139-147$, 1983.

7) Levinson, S.S. and Goldman, J.: Measuring hemoglobin in plasma by reaction with tetramethylbenzidine. Clin. Chem., 28: 471 $-474,1982$.

8) Bessis, M.: Red cell shapes. An illustrated classification and its rationale. Nouv. Rev. Fr. Hematol., 12 : 721-746, 1972.

9) Uda, M., Ohkuma, S., Ishii, A. and Nishizaki, T.: Preparation of blood components with saline-adenine-glucose-phosphate-maltose quadruple-pack system. Transfusion, $25: 325-329$, 1985.

10）大熊重則，宇多正行：赤血球の保存状態の指標と しての morphology score の有用性. 日本輸血学 会雑誌, $32: 523-527,1986$.

11) Rock, G.A., Blanchette, V.S. and Wong, S.C. : Storage of platelets collected by apheresis. Transfusion, 23 : 99-105, 1983.

12）岡田英俊, 宇多正行, 石居昭夫, 西崎大計志: フェ レーシスによって採取した血小板の長期保存法. 日本輸血学会雑誌, $30: 491-493,1984$.

13）大軒子郎, 青木裕紀子, 冨田智津子, 山口英夫, 大久保康人：濃縮血小板血漿保存におけるバッグ の最適表面積比. 日本輸血学会雑誌, $32: 305$, 1986.

14）上平 敦, 中山睦美, 岡崎真人, 小田 貢, 佐藤 暢 : 容器のガス透過性が保存血のガス分圧と機能 に及ぼす影響について。 日本輸血学会雑誌, 29： 694-695, 1984.

15) Dern, R.J., Wiorkowski, J.J. and Matsuda, M. : Studies on the preservation of human blood. V. The effect of mixing anticoagulated blood during storage on the poststorage erythrocyte survival. J. Lab. Clin. Med., 75 : 37-42, 1970.

16）大熊重則, 宇多正行, 石居昭夫, 西崎太計志: 赤 血球製剤の保存中の溶血と糖類によるその抑制効 果. 血液事業, $7: 285-292,1984$.

17) Strumia. and Strumia, P.V.: Conditions affecting the maintenance of ATP, 2,3-DPG and oxygen dissociation by addition of adenine and inosine to blood stored. Transfusion, 12: 68 $-74,1972$.

18) Oski, F.A., Travis, S.F., Miller, L.D. and Delivoria, M. : The in vitro restoration of red cell 2,3-DPG levels in banked blood. Blood, 37 : 52-55, 1971.

19) Wood, L.A. and Beutler, E.: The effect of ascorbate and dihydroxyacetone on the 2,3diphosphoglycerate and ATP levels of stored 
human red cells. Transfusion, 14:272-277, 1974.

20) Brake, J.M. and Deindorfer, F.H.: Preservation of cell 2,3-diphosphoglycerate in stored blood containing dihydroxyacetone. Transfusion, 13 : 84-88, 1973.
21) Hamasaki, N., Ideguchi, Y. and Ikehara, Y.: Regeneration of 2,3-diphosphoglycerate and ATP in stored erythrocytes by phosphoenolpyruvate. A new preservative for blood storage. Transfusion, 21 : 391-396, 1981. 